\title{
Evaluation of iron as a triggering factor for red tide blooms
}

\author{
M. L. Wells ${ }^{1}{ }^{*}$, L. M. Mayer ${ }^{1}$, R. R. L. Guillard ${ }^{2}$ \\ ${ }^{1}$ Department of Oceanography, University of Maine, Ira C. Darling Center, Walpole, Maine 04573, USA \\ ${ }^{2}$ Bigelow Laboratory for Ocean Sciences, McKown Point, Boothbay Harbor, Maine 04575, USA
}

\begin{abstract}
We have examined the relationship between Fe and blooms of the toxic dinoflagellate Alexandrium tamarense (Balech) (formerly Gonyaulax tamarensis var. excavata (Lebour)) using a chemical method that estimates the biological availability of $\mathrm{Fe}$ in seawater. The Fe requirement for optimal growth of $A$. tamarense in sequential batch culture (ca $3 \mathrm{nM}$ 'available' $\mathrm{Fe}$ ) was compared with Fe concentrations in waters of the Gulf of Maine, USA. Results indicated that Fe did not limit growth of the organism in nearshore coastal waters or over Georges Bank, but that the organism may have been Fe-limited in Gulf of Maine basin waters. The distribution of A. tamarense in the Gulf of Maine is consistent with these Fe data. Red tide outbreaks in the nearshore environment did not correlate with changes in total Fe or the estimated Fe availability. Although Fe did not appear to trigger outbreaks of A. tamarense in Maine coastal waters, the findings are consistent with suggestions that pulsed inputs of Fe may be important for the development of toxic dinoflagellate blooms in regions (e.g. Florida) where outbreaks are initiated offshore.
\end{abstract}

\section{INTRODUCTION}

Toxic dinoflagellates flourish in many different regions of the world, generating conditions known as 'red tides', and circumstantial evidence suggests that these occurrences are becoming more frequent (Anderson 1979, Mihnea 1979, Maclean \& White 1985). In the Gulf of Maine, USA, blooms of the saxitoxin-producing dinoflagellate Alexandrium tamarense (Balech), formerly Gonyaulax tamarensis var. excavata (Lebour), develop repeatedly in coastal waters between May and October. These outbreaks are sporadic and often localized, hence difficult to monitor in situ. Effective management of shellfish and aquaculture industries depends on monitoring the saxitoxin concentrations in bivalve tissues, an expensive, labor-intensive process. In consequence, there have been increased efforts to understand the mechanisms triggering red tide outbreaks in order to develop a predictive index to ameliorate health and fisheries management, and to determine the extent to which human activities may increase the frequency and exacerbate the severity of

\footnotetext{
- Present address: Marine Research Division, A-020, Scripps Institution of Oceanography, University of California, San Diego, La Jolla, California 92093, USA
}

these outbreaks. However, there remains considerable uncertainty about the specific conditions necessary for initiating red tide development.

Red tide dinoflagellates, like most dinoflagellates, appear to be well adapted to the early stages of decaying turbulence where nutrient concentrations are relatively high (Margalef et al. 1979, Bowman et al. 1981). For example, blooms often appear along frontal boundaries between water masses (Pingree et al. 1975) or in regions where high tidal energies are dissipated as turbulence (Yentsch et al. 1986). Hydrographic forces may likewise serve to concentrate toxic dinoflagellate populations, contributing to patchiness within a bloom area. Red tides are also often preceded by periods of heavy rainfall (Slobodkin 1953, Collier 1954, Aldrich \& Wilson 1960, Collier et al. 1969, Glover 1978, Smayda \& Packard 1979, Robinson \& Brown 1983). In Swedish coastal waters, blooms of toxic dinoflagellates are most intense in Laholm Bay, which receives 3 times more freshwater input per kilometer of coastline than any other part of the Swedish coast (Graneli et al. 1986). However, because decaying turbulent regimes and runoff do not always result in red tides (Kamykowski 1979, Evans \& Taylor 1980, Martin \& White 1988), these conditions alone are not sufficient to initiate bloom development. 
Efforts to understand the mechanisms of red tide development have focused on the physiochemical conditions associated with increased turbulence and runoff. Because red tides do not correlate consistently with particular temperature, salinity or light regimes, a nutritional 'trigger' has been suspected; that is, a specific nutritional factor, or factors, that stimulate the selective growth of toxic dinoflagellates over that of other phytoplankton when conditions are otherwise (supra)optimal for growth.

Of the possible nutritional triggers, $\mathrm{N}$ or $\mathrm{P}$ does not appear to be involved; Rounsefell \& Dragovich (1966) found no correlation between red tide outbreaks in Florida and organic phosphate, total phosphate, nitrate-nitrite nitrogen, ammonia nitrogen, or total organic nitrogen. Graneli et al. (1986) observed a slight enhancement of toxic dinoflagellate growth in waters from Laholm Bay (Sweden) upon addition of nitrogenand phosphorus-rich agricultural drainage waters. However, even greater growth stimulation occurred with the addition of river water from regions affected by acid rain, and hence rich in trace metals.

Trace metal regimes are known to be an important determinant of phytoplankton species composition, with Fe having perhaps a central role (e.g. Brand et al. 1983, Murphy et al. 1984). Additions of Fe to natural population cultures stimulated the growth of 2 red tide dinoflagellates (Wilson 1966, Martin \& Martin 1973, Graneli et al. 1986) and red tide outbreaks in Florida (USA) correlated strongly with fluvial Fe inputs to coastal waters over a 25 yr period (Ingle \& Martin 1971, Kim \& Martin 1974). The Fe requirement of red tide organisms may be greater than that of other phytoplankton species, as suggested by the almost complete removal of Fe from a red tide-dominated estuary when only moderate Fe removal occurred in a nearby estuary containing a diatom bloom (Matsunaga et al. 1984). Laboratory studies also indicate that red tide species may be more susceptible to iron stress than many other coastal phytoplankton species (Doucette \& Harrison 1990). However, the relationship between Fe and red tide outbreaks has remained ambiguous, primarily because the proportion of total $\mathrm{Fe}$ in seawater that is available to the phytoplankton is unknown. Phytoplankters utilize directly only free (or reactive) soluble Fe species (Anderson \& Morel 1982) which, because of the insolubility of $\mathrm{Fe}$, constitute a small portion of the total Fe in oxic seawater. The bulk of Fe occurs in particulate and probably colloidal forms, which must dissolve to produce the soluble species assimilated by phytoplankton.

We have developed a method for measuring a fraction of the total Fe in seawater which we define as 'labile' iron (i.e. accessible to the measuring technique), and found that the growth of several phyto- plankton species was a direct function of Fe lability (Wells et al. in press). Moreover, we have shown that the labile fraction of total Fe in seawater is not constant, but can differ substantially across small spatial and temporal scales in nature (Wells \& Mayer in press). Therefore, the total Fe content of seawater is not a reliable index to the relationship, if any, between iron requirements of the bloom-forming organism and the development of large populations.

In this study, the relationship between Fe and red tides was re-examined using measurements of labile Fe in seawater. The timing and severity of blooms of the toxic dinoflagellate Alexandrium tamarense in Maine coastal waters were compared with concurrent measurements of total $\mathrm{Fe}$ and $\mathrm{Fe}$ lability. Fe concentrations were also compared with the Fe requirement of $A$. tamarense determined in (sequential) batch cultures. The data were used to evaluate the role of $\mathrm{Fe}$ as a triggering factor for red tide development in Maine coastal waters.

\section{MATERIALS AND METHODS}

Culture experiments. Growth experiments with Alexandrium tamarense (clone GT 429, axenic from the Center for Culture of Marine Phytoplankton, Bigelow Laboratory for Ocean Sciences, Maine) were conducted to determine its minimum Fe requirement for growth and to calibrate this requirement with measurements of labile Fe. Surface seawater was collected by hand off Pemaquid Neck, Maine, (Fig. 1a) in an acidcleaned, 201 low density polyethylene carboy, filtered through acid-washed $0.2 \mu \mathrm{m}$ membrane filters (Nuclepore ${ }^{\circledR}$ polycarbonate) to reduce particulate and colloidal Fe concentrations, and stored in an acid-cleaned, low density polyethylene carboy.

The seawater was enriched with a modification of $f / 2$ nutrients (Guillard \& Ryther 1962); f/2 amounts of nitrate $(883 \mu \mathrm{M})$, phosphate $(36.3 \mu \mathrm{M})$, vitamins (5 to $100 \mu \mathrm{g} \mathrm{l}^{-1}$ ) and $\mathrm{f} / 20$ levels of trace metals Mn (90 nM), Co $(5 \mathrm{nM}), \mathrm{Zn}(8 \mathrm{nM})$, and Mo $(3 \mathrm{nM})$ were added to give the basal growth medium. No artificial chelators were added. $\mathrm{Cu}$ was not added because Alexandrium tamarense is known to be particularly sensitive to cupric ion activity (Anderson \& Morel 1978, Schenck 1984). The basal medium was sterilized by microwaving for $8 \mathrm{~min}^{-1}$ in a 11 teflon bottle (Keller et al. 1988). Culture tubes $\left(60 \mathrm{ml}\right.$ Nalgene ${ }^{\circledR}$ polycarbonate centrifuge tubes with polypropylene caps) were acidwashed, filled with deionized water (Barnstead Nanopure $\left.{ }^{\circledR}\right)$ and sterilized by microwave $\left(5 \operatorname{min~} 1^{-1}\right)$. The tube contents were emptied and $50 \mathrm{ml}$ of the cooled basal medium was pipetted aseptically into each tube using acid-washed, sterile, disposable polypropylene 


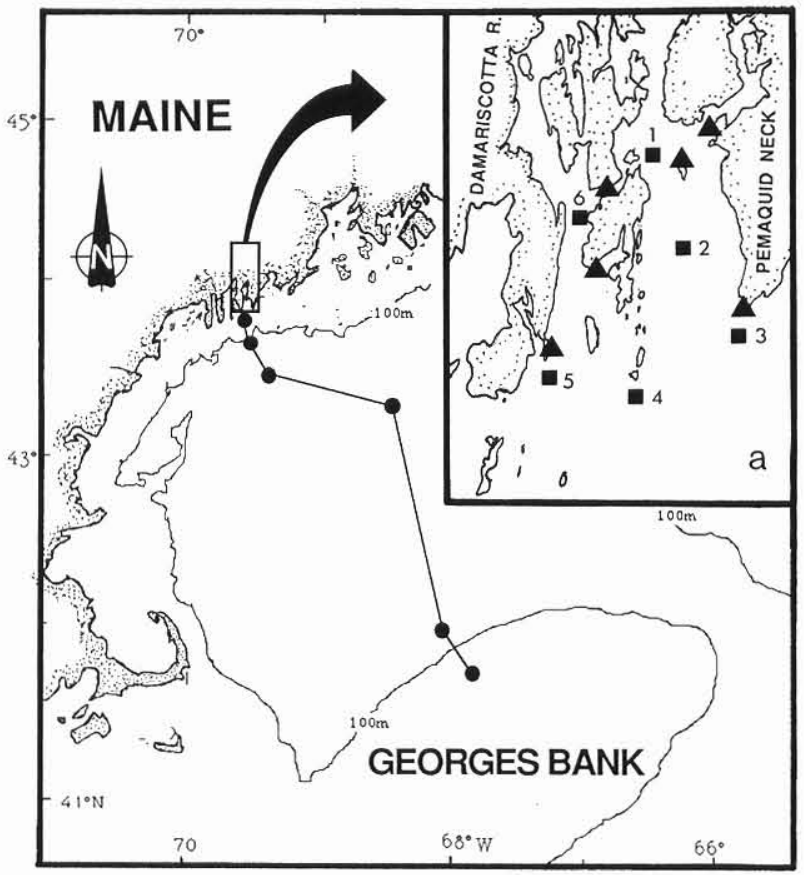

Fig. 1. Sampling stations in the Gulf of Maine, USA. (a) Coastal water sampling stations ( $\mathbf{m})$ and blue mussel shore collection sites (A)

tips. (This procedure avoided clouding of the polycarbonate from contact with hot seawater.)

To minimize $\mathrm{Fe}$ contamination, the vessels and media were handled as described under 'Fe analysis'. Fe contamination in the $\mathrm{N}$ and $\mathrm{P}$ nutrient stocks was minimized by extraction with 8-hydroxyquinoline, also described below. Vitamin and trace metal stocks were prepared from reagent grade chemicals and used without further modification; Fe contamination from these stocks was not significant (see 'Discussion').

$\mathrm{Fe}$ was added to culture tubes from a $4 \times 10^{-4} \mathrm{M}$ ferrihydrite stock prepared by adding $\mathrm{FeCl}_{3} \cdot 6 \mathrm{H}_{2} \mathrm{O}$ to filtered $(0.2 \mu \mathrm{m})$, room temperature deionized water. $\mathrm{Fe}$ in this stock exists as a colloidal precipitate (Wells et al. 1983). Because this Fe stock is altered chemically by either filtration or heating, it was not sterilized before addition to the culture tubes. While conditions in the final growth experiments were therefore not axenic, bacterial populations estimated from microscopic examinations were small, if evident at all.

The Fe requirement of Alexandrium tamarense was determined in 3 consecutive long-term growth experiments, in which the second and third series were inoculated with Fe-deficient cells from the previous series (as in Brand et al. 1983). The initial A. tamarense stock, obtained in standard $\mathrm{f} / 2$ ( $\mathrm{Cu}$ and EDTA added), was maintained through 3 transfers in the modified $\mathrm{f} / 2$ medium described above (plus $100 \mathrm{nM} \mathrm{Fe}$ ) to reduce EDTA concentrations. The stock was then transferred into Fe-'free' medium in order to diminish the cellular Fe levels; reduced cell yields in this culture indicated that $A$. tamarense was Fe-deficient. In the first experiment, a series of culture tubes containing different amounts of ferrihydrite were inoculated from the Fedeficient $A$. tamarense stock, and the tubes placed in a $16^{\circ} \mathrm{C}$ water illuminated at $80 \mu$ Einsteins $\mathrm{m}^{-2} \mathrm{~s}^{-1}$ by fluorescent Vita ${ }^{\circledR}$ lights on a $14: 10$ h light-dark cycle. Growth of the cultures was monitored every 2 or $3 \mathrm{~d}$ by measuring in vivo chlorophyll fluorescence (excitation $465 \mathrm{~nm}$; emission $675 \mathrm{~nm}$ ) with a Perkin Elmer 204 spectrofluorometer adapted for the culture tubes. Measurements of in vivo fluorescence accurately reflect cell numbers of $A$. tamarense (Watras et al. 1982, Schenck 1984). The second and third growth experiments used smaller ferrihydrite additions to better define the Fe-regulated growth response. A separate culture series, with the same nutrient additions as for the bioassay tests, was used for labile Fe determinations (see below).

Field program - water samples. Water samples were collected approximately weekly from mid-April through October 1988 near the mouth of the Damariscotta River estuary at 6 stations situated opposite shoreline collection sites used by the Maine Department of Marine Resources for monitoring red tide outbreaks (Fig. 1a). Water samples of $500 \mathrm{ml}$ were collected from $5 \mathrm{~m}$ depth using an all-teflon MERCOS (Hydrobios) sampler mounted on a nylon line equipped with a plastic-coated weight. This sampling device is suited for trace metal determinations in open ocean environments (Freimann et al. 1983). Surface water temperatures were measured from 'bucket' samples and Secchi depths were recorded at each station. Samples were transported to the laboratory and split for salinity, total $\mathrm{Fe}$, and labile $\mathrm{Fe}$ determinations (see below). Sample processing was completed within $6 \mathrm{~h}$ of water collection.

Gulf of Maine waters were sampled at $10 \mathrm{~m}$ depth along a transect extending from Boothbay Harbor to Georges Bank (Fig. 1). For the collections, the research vessel was positioned into, or oblique to, the wind and the sampling device lowered by hand off the bow. The samples were processed for labile Fe determinations (see below) on board ship under a downflow filtered-air bench (Class 100); Fe analyses were completed onshore.

Field program - toxin levels. The Maine Department of Marine Resources monitors red tide outbreaks along the entire Maine coastline by measuring saxitoxin concentrations in tissues of the blue mussel Mytilus edulis L. and other bivalve species. To evaluate the relationship between Fe and red tides, blue mussel saxitoxin data from the study area (Fig. 1a) were compared with the concentrations of labile and total $\mathrm{Fe}$ 
measured at the nearby water sampling sites. The blue mussel rapidly accumulates and eliminates dinoflagellate saxitoxins, making it an ideal indicator species (Yentsch \& Incze 1979) as well as an integrator of the relative numbers of Alexandrium tamarense in the surrounding waters. Saxitoxin concentrations in whole body blue mussel homogenates were determined by the standard mouse bioassay used for paralytic shellfish poison analysis (AOAC 1965, Hurst \& Yentsch 1981).

Fe analysis. Concentrations of chemically labile Fe were measured with a technique that utilizes the chelating agent 8-hydroxyquinoline (oxine) (Wells et al. in press). Briefly, $1 \mathrm{ml}$ of purified $6.15 \mathrm{mM}$ oxine was added to $100 \mathrm{ml}$ of unfiltered sample water. The samples were buffered to $\mathrm{pH} 6$ with $1 \mathrm{M}$ sodium phosphate (monobasic). After $1 \mathrm{~h}$, during which the oxine complexed labile (or reactive) $\mathrm{Fe}$, the samples were drawn by vacuum through $\mathrm{C}_{18}$ columns (Sep-Pak ${ }^{\circledR}$ ) which retained the oxine-Fe complexes. The complexes were eluted from the columns with $2 \mathrm{ml}$ of distilled methanol and the $\mathrm{Fe}$ in the eluates measured by graphite furnace atomic absorption (GFAA). The $\mathrm{C}_{18}$ columns were precleaned to remove $\mathrm{Fe}$ contamination by repeated sequential washes with the oxine-buffer and methanol reagents, the methanol eluate of the final cleaning step being retained for a reagent plus column blank. Recoveries of acidified Fe spikes from seawater were $100 \% \pm 6 \%$. The detection limit for $100 \mathrm{ml}$ of sample was ca $1 \mathrm{nM}$ Fe.

In order to determine the extent to which naturally occurring organic-Fe phases were retained on the $\mathrm{C}_{18}$ columns, and thus would be enumerated as oxinelabile $\mathrm{Fe}^{\prime}$, seawater samples buffered to $\mathrm{pH} 6$ were processed without added oxine. The Fe concentration in these tests were $<10 \%$ of those measured with oxine added. Similarly, when dense phytoplankton cultures were processed without added oxine, the organic-Fe fraction retained on the $\mathrm{C}_{18}$ columns was $<5 \%$ of that measured with oxine. Because these values were within the level of precision for the oxine technique, no correction factors were applied to field measurements.

For total Fe determinations, $30 \mathrm{ml}$ of unfiltered sample water were acidified to $\mathrm{pH} 1.6$ with ultrapure $\mathrm{HCl}$ and aged a minimum of $2 \mathrm{wk}$ at room temperature before analysis. Total (acid-solubilized) Fe was then determined by either direct injection GFAA, or by oxine preconcentration (as above) after adjusting the sample $\mathrm{pH}$ to 5 to 6 with ultrapure $\mathrm{NH}_{4} \mathrm{OH}$ (Fe recoveries with oxine at $\mathrm{pH}<4$ are not quantitative). Intercomparisions showed a reasonable correspondence between these methods.

Ultra-clean techniques were employed throughout sample collection, processing and Fe analyses. All sam- ple manipulations and oxine treatments were done under a downflow filtered-air bench (Class 100). The bottles were soaked a minimum of $24 \mathrm{~h}$ in $10 \%$ (reagent grade) $\mathrm{HCl}$, rinsed with deionized water, and resoaked in $5 \%$ ultrapure $\mathrm{HCl}$ for a minimum of $12 \mathrm{~h}$. The bottles were rinsed thoroughly with deionized water immediately before use. Reagents used in the Fe analyses were purified to minimize Fe contamination. Ultra-pure $\mathrm{HCl}$ and $\mathrm{NH}_{4} \mathrm{OH}$ were prepared by subboiling distillation of reagent grade materials in a polypropylene still. Reagent grade oxine was purified by vacuum sublimation at $120^{\circ} \mathrm{C}$ onto a cold finger (Honjo et al. 1978); the phosphate buffer was cleaned by repeated extractions with purified oxine. Glassdistilled methanol was used for cleaning the columns and eluting the samples. Reagents were prepared in small batches and stored in acid-cleaned polypropylene bottles until use.

\section{RESULTS}

\section{Growth experiments}

Growth of Alexandrium tamarense with different amounts of added ferrihydrite was preceded by a lag phase of about $10 \mathrm{~d}$ (Fig. 2a, b). There was little if any

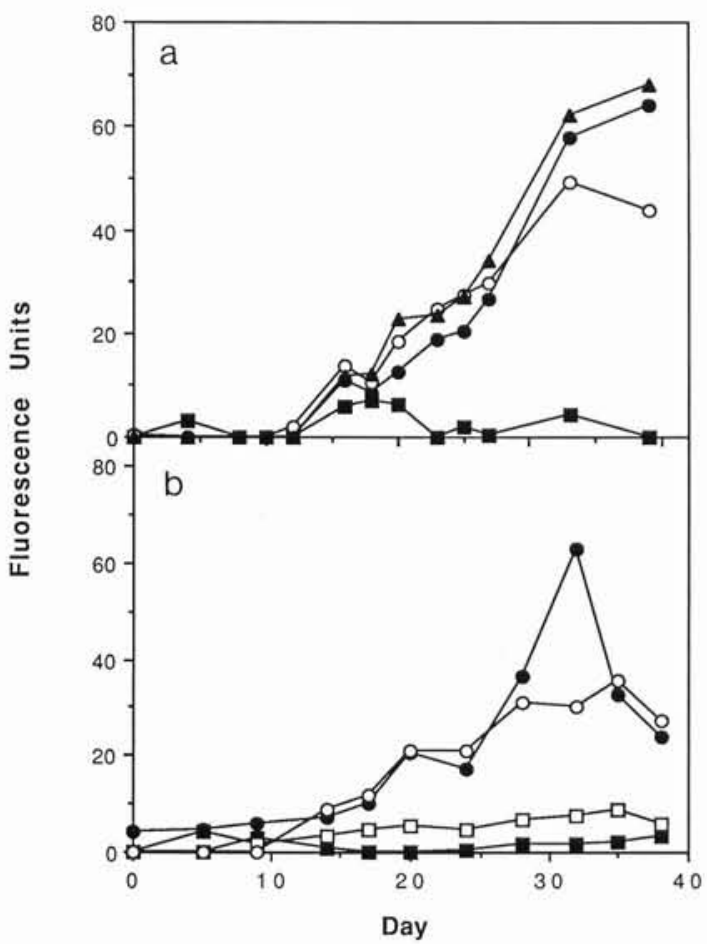

Fig. 2. Alexandrium tamarense. Growth response in sequential $(\mathrm{a}, \mathrm{b})$ batch cultures with added ferrihydrite. Fe additions: (घ) no added $\mathrm{Fe}$; (ㅁ) $5 \mathrm{nM}$ ferrihydrite; (•) $10 \mathrm{nM}$ ferrihydrite; (ㅇ) $25 \mathrm{nM}$ ferrihydrite; (४) $50 \mathrm{nM}$ ferrihydrite 
growth of A. tamarense without ferrihydrite added and growth improved only slightly with $5 \mathrm{nM}$ ferrihydrite (Fig. 2b). Larger additions of ferrihydrite $(10,25$, $50 \mathrm{nM}$ ) gave substantially better growth than did $5 \mathrm{nM}$ ferrihydrite; however, growth differences among these (higher) $\mathrm{Fe}$ tests were small. Using fluorescence as relative index of cell number (Watras et al. 1982, Schenck 1984), the maximum slope of fluorescence increase in the 10 to $50 \mathrm{nM}$ ferrihydrite tests corresponded with a growth rate of ca 0.5 divisions $\mathrm{d}^{-1}$. Maximum densities of $A$. tamarense, estimated from a fluorescence-cell number regression (unpubl.), were on the order of $1 \times 10^{7}$ cells $1^{-1}$.

The organism's Fe-regulated growth response was calibrated with oxine-labile Fe (oxine-Fe) by measuring $\mathrm{Fe}$ concentrations in a separate series of culture preparations (Fig. 3). Oxine-Fe concentrations were

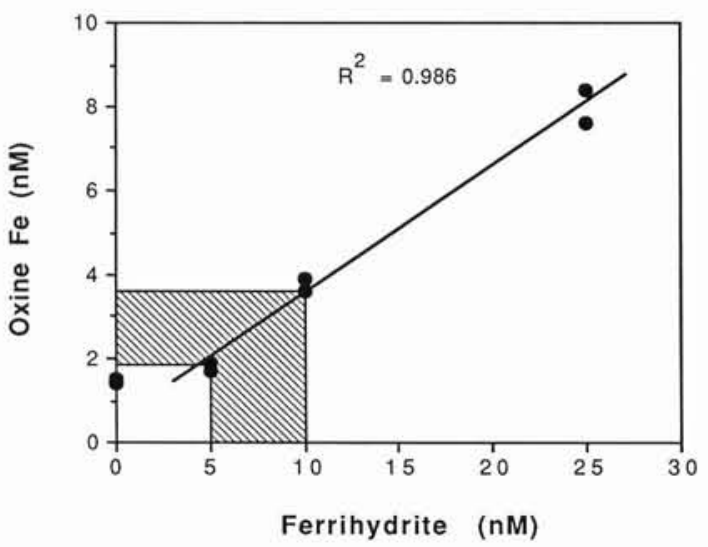

Fig. 3. Concentrations of oxine-Fe in the culture media with ferrihydrite additions. Hatched area denotes the threshold between Fe-replete and Fe-deplete conditions

measured immediately after the media preparation so the values in Fig. 3 represent those at the start of the bioassays (i.e. before significant ferrihydrite hydrolysis or cellular uptake of Fe). The concentration of oxine-Fe in the control (seawater enriched with $\mathrm{N}, \mathrm{P}$, trace metals, and vitamins but not $\mathrm{Fe}$ ) was $1.5 \mathrm{nM} \mathrm{Fe}$, essentially at the limit of analytical detection (1.0 nM). Oxine-Fe concentrations increased proportionally with the amount of ferrihydrite added, accounting for ca $35 \%$ of the total Fe. Based on the growth response, conditions shifted from Fe-limited to Fe-replete between 5 and $10 \mathrm{nM}$ of added ferrihydrite (Fig. 2a, b), corresponding to a limiting threshold value of ca $3 \mathrm{nM}$ oxine-Fe (Fig. 3). While some growth occurred below this threshold value, more Fe was needed for sustained growth under these bioassay conditions (Fig. 2b).

\section{Field survey - Fe}

There was considerable range in total Fe concentrations in the study area, with values extending from 25 to $1445 \mathrm{nM}$ (Fig. 4 a). At stations where the tidal currents were relatively small (Stns 3 and 4), values showed some indication of a seasonal distribution, with higher concentrations occurring in the spring and fall than in summer (Fig. 4a). Spatial differences also

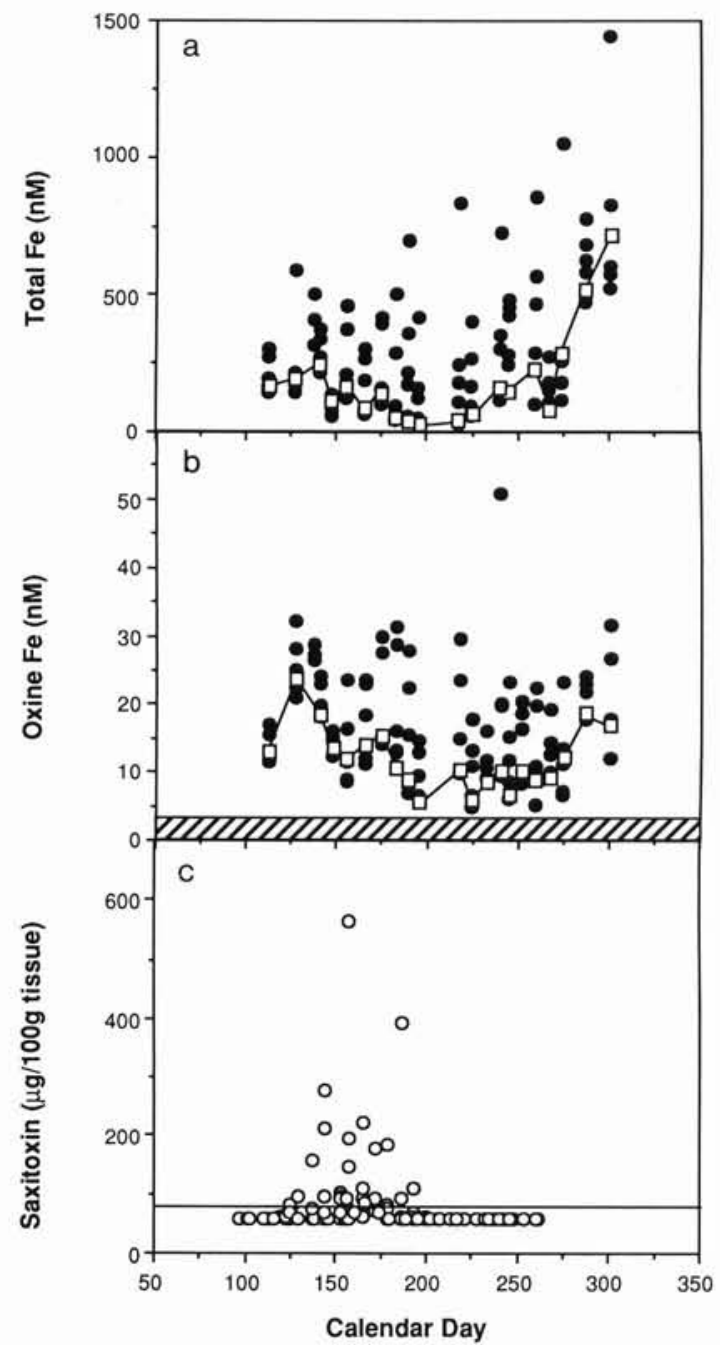

Fig. 4. Concentrations of (a) total Fe, (b) oxine-Fe, and (c) saxitoxin in blue mussel tissues, in the study area during 1988. For the most part, there were no seasonal trends in the total and oxine-Fe data with the exception of Stns 3 and 4 (Fig. 1) which showed some indication of seasonality; only data points from Stn 4 (ㅁ) are shown connected for simplicity. The hatched area in (b) shows the concentrations of oxine-Fe at which Alexandrium tamarense would be limited by $\mathrm{Fe}$, according to the bioassay results. The detection limit for tissue toxin concentrations, measured by the standard mouse bioassay, was $58 \mu \mathrm{g}(100 \mathrm{~g} \text { tissue })^{-1}$. The quarantine level $(80 \mu \mathrm{g}(100 \mathrm{~g}$ tissue) $)^{-1}$ ) is marked in (c) 
occurred among the stations on any given day, the total Fe concentrations being consistently higher at stations subject to strong tidal currents (Wells \& Mayer in press).

Concentrations of oxine-Fe ranged from 5 to $50 \mathrm{nM}$ $\mathrm{Fe}$ and also showed some indication of seasonality at Stns 3 and 4 (Fig. 4b). Oxine-Fe concentrations were not found to decrease below $3 \mathrm{nM}$, the threshold value indicated in the growth experiments to cause Fe limitation of Alexandrium tamarense (but values did come within a factor of 2 at Stns 3 and 4). As seen with total $\mathrm{Fe}$, concentrations of oxine-Fe were consistently higher at the stations where tidal currents were stronger, probably because of sediment resuspension or enhanced vertical mixing of bottom waters rich in oxine-Fe and total Fe (unpubl.).

Oxine-Fe concentrations in the Gulf of Maine surface waters (July 1988) decreased rapidly with increasing distance from shore, with values changing from ca $8 \mathrm{nM}$ oxine-Fe at the coast to near or below detection (ca $1 \mathrm{nM}$ ) within $45 \mathrm{~km}$ offshore (Fig. 5). Over Georges Bank ( $270 \mathrm{~km}, 30 \mathrm{~m}$ deep), the oxine-Fe concentrations were considerably higher $(10.9 \mathrm{nM})$ than at the nearby deep water station ( $\leq 1 \mathrm{nM} ; 235 \mathrm{~km}, 223 \mathrm{~m}$ deep). A similar distribution pattern of total Fe was found; concentrations diminished quickly from inshore $(49 \mathrm{nM})$ to offshore ( $\leq 2 \mathrm{nM} ; 45 \mathrm{~km}$ ), remained low in the Gulf of Maine basin $(\leq 2 \mathrm{nM})$, and increased again over Georges Bank (93 nM) (Wells \& Mayer in press).

\section{Field survey - tissue toxin}

Red tides occurred in the study area during the late spring and early summer of 1988 (Fig. 4c). Tissue saxitoxin concentrations increased well above the quarantine limit $\left(80 \mu \mathrm{g}(100 \mathrm{~g} \text { tissue })^{-1}\right)$ at all 6 mussel sam-

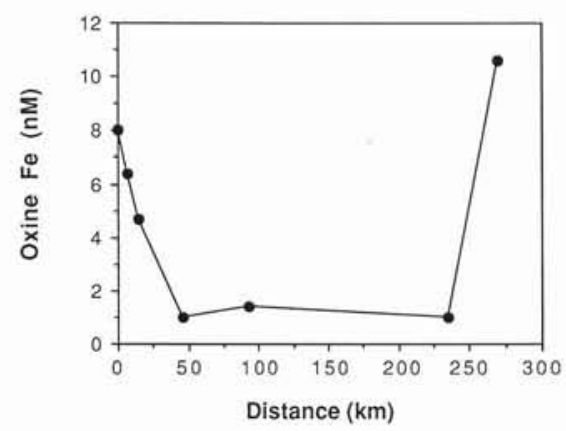

Fig. 5. Oxine-Fe concentrations at $10 \mathrm{~m}$ depth in the Gulf of Maine in July 1988 (Calendar Days 192 to 195). Station locations are shown in Fig. 1. Distances are those along the transect from Boothbay Harbor to Georges Bank $(270 \mathrm{~km})$. The shore station value $(0 \mathrm{~km})$ is the mean of oxine-Fe values measured at the headland stations ( 3 and 4 ; Fig. 1 ) on Calender Day 189

pling stations on several occasions. Although all stations were affected, the timing and severity of the Alexandrium tamarense blooms differed slightly among stations (data not shown). There was no clear relationship between tissue saxitoxin concentrations and concurrent in situ measurements of oxine-Fe and total Fe (Fig. 6a, b). In contrast to most earlier years, no red tides developed during the fall in 1988, in spite of the apparent general increase in Fe availability in the study area (Fig. 4b).

\section{DISCUSSION}

Rigorous testing of the relationship between Fe and red tides has not been possible without methods for estimating biologically available $\mathrm{Fe}$ in seawater. Because $\mathrm{Fe}$ in seawater should occur principally in colloidal or particulate forms, Fe availability is likely
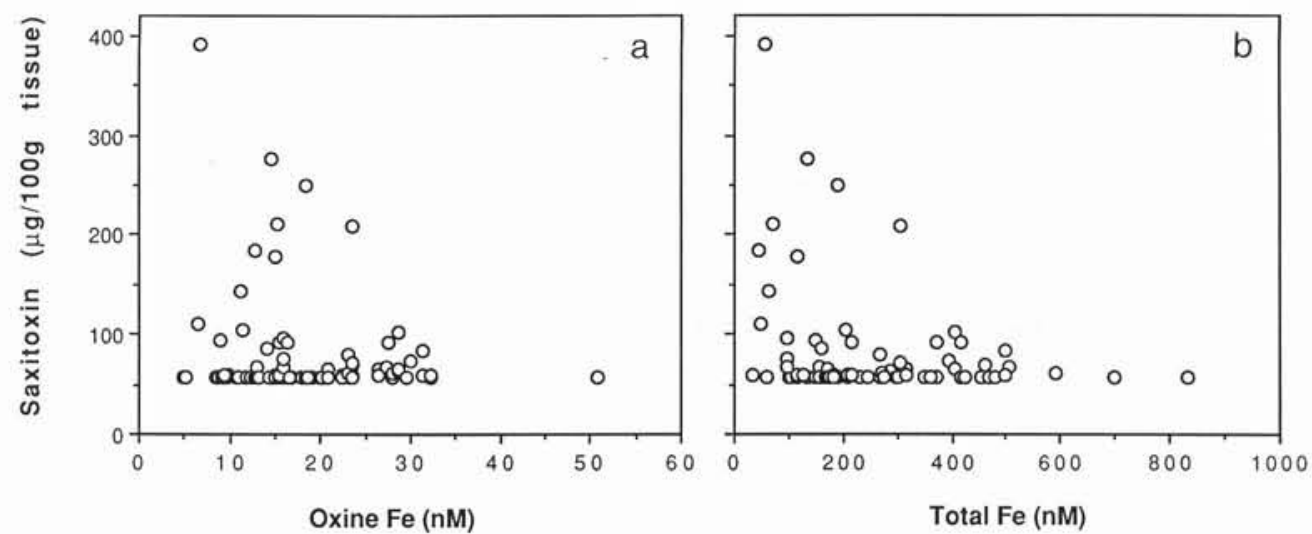

Fig. 6. Tissue saxitoxin concentrations of blue mussels vs Fe: (a) oxine-Fe, (b) total Fe. The data plotted are from the 6 tissue sampling stations and from 4 water sampling stations opposite these shore sites; data from water sampling Stns 2 and 4 are excluded here 
dependent on dissolution kinetics which replenish the soluble pool of free (reactive) Fe used by phytoplankton. Presumably, a faster dissolution rate of solid $\mathrm{Fe}$ forms (i.e. more chemically labile) should lead to a greater potential supply of Fe to phytoplankton. Fe limitation should result when the phytoplankton demand exceeds Fe dissolution rates.

In the oxine technique, adding oxine in excess over total Fe simulates, in a broad sense, a high 'biological' demand for Fe through complexation ('uptake') of soluble Fe which, in turn, induces colloid and particle dissolution. This analogy is imperfect because oxine may additionally enhance dissolution by direct interaction with the solid Fe surface. While even highly crystalline materials (e.g. goethite, hematite) ultimately can dissolve in seawater, biologically available Fe would comprise only those forms dissolving on time scales relevant to phytoplankton generation rates, something crystalline materials apparently cannot do (e.g. Wells et al. 1983). We have found that only the more labile Fe forms, measured by $1 \mathrm{~h}$ of reaction time with oxine, appear to be proportional to Fe availability; $1 \mathrm{~h}$ oxineFe measurements correlate positively with the extent to which different Fe oxyhydroxides support phytoplankton growth in cultures (Wells et al. in press). Thus, the oxine technique offers a means for testing in situ the hypothesis that red tide outbreaks are initiated by increases in $\mathrm{Fe}$ availability.

Growth in the bioassays was preceded by a lag phase of about $10 \mathrm{~d}$ that likely reflected the poor physiological state of the Fe-depleted inoculum; for example, the normal lag time for the red tide dinoflagellate Gymnodinium sanguineum in culture (ca $3 \mathrm{~d}$ ) increases to 7 to $8 \mathrm{~d}$ under Fe-deficient conditions (Doucette pers. comm.). Growth differences among the tests after the $10 \mathrm{~d}$ lag are interpreted as illustrating the relative state of Fe nutrition. The results indicate that the minimal $\mathrm{Fe}$ requirement of Alexandrium tamarense in batch culture is $>1.8 \mathrm{nM}$ of oxine-Fe; although some growth occurred at this level of $\mathrm{Fe}$, it was not sustained over the duration of the bioassay (Fig. 2b). By comparison, doubling the oxine-Fe concentration to $3.8 \mathrm{nM}$ gave sustained growth for weeks at rates in the maximum range reported for A. tamarense in batch cultures (Watras et al. 1982, Anderson et al. 1984, Schenck 1984). Further, the maximum cell densities with $\geq 3.8 \mathrm{nM}$ oxine-Fe were on the order of $10^{7}$ cells $1^{-1}$, which is 3 orders of magnitude greater than concentrations shown to cause extremely toxic shellfish in nature (Yentsch \& Mague 1979). It therefore seems that the $3 \mathrm{nM}$ threshold of oxine-Fe is a reasonable first approximation for distinguishing Fe-deplete from Fe-replete conditions for A. tamarense, and that severe red tide outbreaks are possible at only moderately higher concentrations of oxine-Fe.
It is important to emphasize here the empirical and approximate nature of the $3 \mathrm{nM}$ threshold value. Ferrihydrite is chemically unstable, the bond structure being altered over time by dehydration of the polymeric $\mathrm{Fe}\left(\mathrm{OH}, \mathrm{H}_{2} \mathrm{O}\right)$ precipitate (Van der Giessen 1968, Murray 1979, Eggleton \& Fitzpatrick 1988). These alterations lead to decreased solubility, lability and (hence) biological availability of the colloidal Fe (Wells et al. 1983, Wells et al. in press). The time-dependent maturation process, combined with the increasing $\mathrm{Fe}$ demand associated with greater cell abundances, should have diminished Fe availability as the bioassay progressed. The $3 \mathrm{nM}$ oxine-Fe threshold (measured at time zero) may therefore overestimate the actual $\mathrm{Fe}$ requirement of Alexandrium tamarense, with sustained growth perhaps being possible with a smaller, but continuous, supply of Fe. Additional complication comes from the possibility of 'luxury' uptake of Fe by $A$. tamarense; most or all the Fe needed for growth may have been taken up within the first few days, before the rates of cell metabolism increased. Thus, the bioassay results are best employed to indicate the $\mathrm{Fe}$ reserve needed for bloom development if no new Fe was introduced to surface waters.

Oxine-Fe concentrations in the growth medium increased with additions of ferrihydrite at a consistent proportion (ca $35 \%$ ) of the total Fe added (Fig. 3). This proportion was roughly half of that measured for ferrihydrite in unenriched seawater (Wells et al. in press) indicating that one or more of the enrichment constituents rendered ferrihydrite less labile. One possible explanation would be phosphate adsorption or co-precipitation with ferrihydrite; adsorption of the added trace metals to ferrihydrite may also have contributed to the decrease in its lability. The effect of such indirect factors on Fe availability cannot be resolved from these data.

The coastal area chosen to test the relationship between $\mathrm{Fe}$ and red tide development is a region where red tides have been recorded frequently since monitoring began in 1972. These red tides are characteristic of those in other regions of the Maine coast, being patchy, temporally discontinuous events generally occurring between May and October. The outbreaks are believed to originate primarily by an autochthonous mechanism (excystment of resting stages overwintering in the underlying sediments), but the shoreward advection of offshore populations might be important at the headland site (Stn 3) on Pemaquid Neck (J.W. Hurst pers comm. 1988). There are no major freshwater inputs to the study area, although the region is influenced by runoff from the Penobscot River situated $100 \mathrm{~km}$ to the northeast. During 1988, red tide outbreaks occurred repeatedly in the study area and the bloom intensities, inferred from the saxitoxin con- 
centrations in blue mussel tissues, were similar to those in earlier years (Thayer et al. 1983, J. Hurst pers. comm. 1988).

The change in blue mussel tissue saxitoxin concentrations did not correlate with either water temperature or salinity (data not shown), concordant with the findings of other studies (Mulligan 1975, Sweeney 1975, Martin \& White 1988). Tissue saxitoxin concentrations also were not related to water clarity, as measured by Secchi depth. (Light data were not available for comparison.) Although these factors undoubtedly constrain the conditions suitable for red tide outbreaks, the results suggest that these variables did not initiate bloom development.

For changes in Fe availability to be a direct cause of red tide outbreaks it is necessary that Alexandrium tamarense normally experience Fe-limitation in coastal waters, such that increases in Fe availability initiate its rapid growth. However, at no time did oxine-Fe concentrations in surface waters decrease below the $3 \mathrm{nM}$ threshold estimated to cause Fe limitation. Although values did come within a factor of 2 of this threshold ( 5 to $6 \mathrm{nM}$ ) at the headland stations ( 3 and 4) during summer, when water column stratification would be greatest, oxine-Fe concentrations at the other stations remained considerably higher, probably as a result of tidally-induced vertical mixing (unpubl.). Moreover, based on the high bioassay cell densities generated with $3.8 \mathrm{nM}$ oxine-Fe, it appears that the availability of Fe in the study area was sufficient not only for rapid cell growth, but also for heavy bloom development throughout the sampling period.

With Alexandrium tamarense apparently not limited by $\mathrm{Fe}$ in these waters, there is little reason to expect that in situ concentrations of oxine-Fe would reflect its abundance. Indeed, there was no correlation between oxine-Fe and tissue saxitoxin concentrations, the index of A. tamarense populations (Fig. 6a). To test the possibility that pulsed changes in Fe caused a time-delayed growth signal (due to the relatively long generation times of $A$. tamarense), tissue toxin concentrations were compared with surface water oxine-Fe concentrations measured 1,2 , and $3 \mathrm{wk}$ earlier, but still no association was found (data not shown). Measurements of oxine-Fe were therefore a poor indicator of red tides.

In drawing comparisons between oxine-Fe and tissue saxitoxin data we recognize that cellular toxin levels can be variable and are poorly defined in natural systems. As a result, blue mussel saxitoxin data may not have reflected consistently the abundance of Alexandrium tamarense cells. Nonetheless, because the primary goal of this study was to determine whether estimates of $\mathrm{Fe}$ availability could assist in predicting the occurrence of poisonous shellfish, correlations between bivalve toxicity and Fe were considered most meaningful.
It should be remembered that oxine-Fe analyses were performed on unfiltered water samples and thus the values comprise the oxine-lability of both dissolved $(<0.4 \mu \mathrm{m})$ and particulate $(>0.4 \mu \mathrm{m}) \mathrm{Fe}$ phases. Although biologically available Fe is generally considered to occur in the dissolved fraction, discrimination between dissolved and particulate fractions likely has limited relevance when considering Fe availability; by utilizing free (reactive) $\mathrm{Fe}$, the phytoplankton ultimately draw upon all Fe forms regardless of substrate size. We have found, for instance, that a substantial proportion of oxine-Fe often resides in the particulate phase (Wells \& Mayer in press). The summed lability of dissolved and particulate fractions should therefore provide a better estimate of the availability of $\mathrm{Fe}$ in seawater.

Offshore in the Gulf of Maine, oxine-Fe concentrations decreased below $3 \mathrm{nM}$ beyond about $25 \mathrm{~km}$ from shore, and were near or below detection (1 nM) at the 3 basin stations (Fig.5). Fe availability in the basin waters may therefore have been too low to support sustained growth of Alexandrium tamarense. Although Dinophyceans are often the second most abundant phytoplankton group in the Gulf of Maine basin, their numbers are generally low, and Gonyaulax spp. (which until recently included $A$. tamarense) are a small component of the dinoflagellates present (Marshall \& Cohn 1983, Marshall 1984a, b). In contrast, oxine-Fe concentrations over Georges Bank $(10.6 \mathrm{nM})$ exceeded even those measured in coastal waters, and there is some evidence that red tide outbreaks occur here (J. Hurst pers. comm. 1988). The distribution of A. tamarense populations is therefore consistent with the pattern of estimated Fe availability in the Gulf of Maine.

Outbreaks of Alexandrium tamarense in Maine coastal waters did not correspond with changes in total $\mathrm{Fe}$ concentrations (Fig. 4b), in contrast with blooms of the toxic dinoflagellate Ptychodiscus breve (formerly Gymnodinium breve) in Florida which correlated positively with total riverine inputs of Fe over a $25 \mathrm{yr}$ period (Ingle \& Martin 1971, Kim \& Martin 1974). However, the latter correlation is equivocal. Firstly, total Fe concentrations were not monitored at the sites of bloom initiation off the Florida coast; Fe concentrations at these initiation sites might not have been a function of river runoff. Secondly, outbreaks may have instead been related mechanistically to other riverine constituents changing in concert with Fe (e.g. humic substances; Prakash \& Rashid 1968). However, the unique importance of $\mathrm{Fe}$ for red tide development has been implicated directly in other bloom site studies (Matsunaga et al. 1984), in enrichment experiments (Wilson 1966, Martin \& Martin 1973, Graneli et al. 1986) and in physiological studies (Doucette \& Harrison 1990). The lack of correlation 
between $\mathrm{Fe}$ and red tides reported here may indicate that A. tamarense (clone GT429) has a lower Fe requirement than other toxic dinoflagellates, rendering it less sensitive to changes in Fe availability; too few data on dinoflagellate $\mathrm{Fe}$ requirements presently exist to allow comparison among species. Alternatively, the differing results from Florida and Maine waters may be related to the sites of bloom inititation. Florida red tides usually initiate 18 to $74 \mathrm{~km}$ offshore and are transported inshore by winds, tides and currents (Roberts 1979); as many as three-fourths of these offshore 'microblooms' terminate before being advected inshore (Steidinger 1975), suggesting that nutrient conditions are usually inadequate for bloom development. By comparison, red tides in Maine coastal waters often appear to develop autochthonously within the inshore environment (J. Hurst pers. comm. 1988). Were they to initiate offshore instead, as in Florida, the oxine-Fe data suggest that pulsed inputs of available Fe could be critical for bloom development.

Because Alexandrium tamarense became Fe-limited at oxine-Fe levels that were measurable in cultures and in the field, we suggest that the oxine technique be used to determine whether other phytoplankton species are Fe-limited in seawater. In particular, the $\mathrm{Fe}$ requirement of Ptychodiscus breve should be determined in culture and compared with concentrations of oxine-Fe in waters off the Florida coast where blooms initiate. In this respect, it would be crucial that the oxine-Fe threshold for growth be determined with great accuracy because Fe concentrations in offshore waters are much lower and less variable than in coastal waters. Oxine-Fe organism growth rate calibrations could be refined by using continuous or semi-continuous culturing techniques, thus reducing some of the uncertainties associated with long-term batch methods. Still better would be to relate oxine-Fe measurements to short-term Fe uptake rates using ${ }^{59} \mathrm{Fe}$. In this way, $\mathrm{Fe}$ uptake rates could be isolated from crop production factors and might prove to be a more direct index for estimating Fe nutrition in seawater.

Acknowledgements. We thank John Hurst of the Maine Department of Marine Resources for providing the blue mussel saxitoxin data and for his helpful discussions. We also thank Dr Gary King for his assistance in the preparation of this manuscript and the reviewers for their helpful comments. This work was supported by Sea Grant No. R/FMD-161.

\section{LITERATURE CITED}

Aldrich, D. V., Wilson, W. (1960). The effect of salinity on the growth of Gymnodinium breve Davis. Biol. Bull. mar. biol. Lab., Woods Hole 119: 57-64

Anderson, D. M. (1979). The role of chelators and trace metals in toxic blooms. In: Taylor, D. L., Seliger, H. H. (eds.) Toxic dinoflagellate blooms, Proc. Sec. Intern. Conf. on Toxic Dinofl. Blooms. Elsevier, Amsterdam, p. 463-467

Anderson, D. M., Kuilis, D. M., Binder, B. J. (1984). Sexuality and cyst formation in the dinoflagellate Gonyaulax tamarensis: cyst yield in batch cultures. J. Phycol. 20: 418-425

Anderson, D. M., Morel, F. M. M. (1978). Copper sensitivity of Gonyaulax tamarensis. Limnol. Oceanogr. 23: 283-295

Anderson, M. A., Morel, F. M. M. (1982). The influence of aqueous iron chemistry on the uptake of iron by the coastal diatom Thalassiosira weissflogii. Limnol. Oceanogr. 27: $789-813$

Association of Official Agricultural Chemists (AOAC) (1965). Paralytic shellfish poison, biological method (18). Official methods of analysis of the association of official agricultural chemists, 10th edn. Washington, D.C., p. 282-284

Bowman, M. J., Esaias, W. E., Schnitzer, M. B. (1981). Tidal stirring and the distribution of phytoplankton in Long Island and Block Island Sounds. J. mar. Res. 39: 587-603

Brand, L. E., Sunda, W. G., Guillard, R. R. L. (1983). Limitation of marine phytoplankton reproductive rates by zinc, manganese and iron. Limnol. Oceanogr. 28: 1182-1198

Collier, A. W. (1954). Gulf fishery investigations. U.S. Fish and Wildl. Serv., Annual Report for Fiscal Year 1954, Branch of Fishery Biology, p. 23-25

Collier, A., Wilson, W. B., Borkowski, M. (1969). Responses of Gymnodinium breve Davis to natural waters of diverse origin. J. Phycol. 5: 168-172

Doucette, G. J., Harrison, P. J. (1990). Some effects of iron and nitrogen stress on the red tide dinoflagellate Gymnodinium sanguineum. Mar. Ecol. Prog. Ser. 62: 293-306

Eggleton, R. A., Fitzpatrick, R. W. (1988). New data and a revised structural model for ferrihydrite. Clays Clay Min. 36: $111-124$

Evans, G. T., Taylor, F. J. R. (1980). Phytoplankton accumulation in Langmuir cells. Limnol. Oceanogr. 25: 840-845

Freimann, P., Schmidt, D., Schomaker, K. (1983). MERCOS A simple teflon sampler for ultratrace metal analysis in seawater. Mar. Chem. 14: 43-48

Glover, H. E. (1978). Iron in marine coastal waters; seasonal variation and its apparent correlation with a dinoflagellate bloom. Limnol. Oceanogr. 23: 534-537

Graneli, E., Persson, H., Edler, L. (1986). Connection between trace metals, chelators and red tide blooms in the Laholm Bay, SE Kattegat - An experimental approach. Mar. environ. Res. 18: 61-78

Guillard, R. R. L., Ryther, J. H. (1962). Studies of marine planktonic diatoms. I. Cyclotella nana Hustedt, and Detonula confervacea (Cleve). Gran. Can. J. Microbiol. 8: 229-239

Honjo, T., Imura, H., Shima, S., Kiba, T. (1978). Vacuum sublimation behavior of various metal chelates of 4anilino-3-pentene-2-one, acetylacetone, dithiocarbamates, oxine and its derivatives, dimethylglyoxime, dithizone, 1(2-pyridylazo)-2-naphthol, and tetraphenylporphyrin. Analyt. Chem. 50: 1545-1552

Hurst, J. W., Yentsch, C. M. (1981). Patterns of intoxication of shellfish in the Gulf of Maine coastal waters. Can. J. Fish. Aquat. Sci. 38: 152-156

Ingle, R. M., Martin, D. F. (1971). Prediction of the Florida red tide by means of the iron index. Envir. Letters 1: 69-74

Kamykowski, D. (1979). Growth response of a model Gymnodinium spendens in stationary and wavy water columns. Mar. Biol. 50: 289-303

Keller, M. D., Bellows, W. K., Guillard, R. R. L. (1988). Microwave treatment for sterilization of phytoplankton culture media. J. exp. mar. Biol. Ecol. 117: 279-283 
Kim, Y. S., Martin, D. F. (1974). Interrelationship of Peace river parameters as a basis of the iron index: a predictive guide to the Florida red tide. Wat. Res. 8: 607-616

Maclean, J. L., White, A. W. (1985). Toxic dinoflagellate blooms in Asia: a growing concern. In: Anderson, D. M., White, A. W., Baden, D. G. (eds.) Toxic dinoflagellates. Proc. Third Intern. Conf. on Toxic Dinofl. Blooms. Elsevier, Amsterdam, p. 517-520

Margalef, R., Estrada, M., Blasco, D. (1979). Functional morphology of organisms involved in red tides, as adapted to decaying turbulence. In: Taylor, D. L., Seliger, H. H. (eds.) Toxic dinoflagellate blooms, Proc. Sec. Intern. Conf. on Toxic Dinofl. Blooms. Elsevier, Amsterdam, p. 89-94

Marshall, H. G. (1984a). Phytoplankton distribution along the eastern coast of the USA. Part V. Seasonal density and cell volume patterns for the north-eastern continental shelf. J. Plankton Res. 6: 169-193

Marshall, H. G. (1984b). Phytoplankton of the northeastern continental shelf of the United States in relation to abundance, composition, cell volume, seasonal, and regional assemblages. Rapp. P.-v. Reun. Cons. int. Explor. Mer 183: 41-50

Marshall, H. G., Cohn, M. S. (1983). Distribution and composition of phytoplankton in northeastern coastal waters of the United States. Estuar. coast. Shelf Sci. 17: 119-131

Martin, D. F., Martin, B. B. (1973). Implications of metal organic interactions in red tide outbreaks. In: Singer, P. C. (ed.) Trace metals and metal-organic interactions in natural waters. Ann Arbor Sci., Ann Arbor, Michigan, p. 339-362

Martin, J. L., White, A. W. (1988). Distribution and abundance of the toxic dinoflagellate Gonyaulax excavata in the Bay of Fundy. Can. J. Fish. Aquat. Sci. 45: 1968-1975

Matsunaga, K., Igarashi, K., Fukase, S., Tsubota, H. (1984). Behavior of organically-bound iron in seawater of estuaries. Estuar. coast. Shelf Sci. 18: 615-622

Mihnea, P. E. (1979). Some specific features of dinoflagellate Exuviaella cordata Ostf. blooming in the Black Sea. In: Taylor, D. L., Seliger, H. H. (eds.) Toxic dinoflagellate blooms. Proc. Sec. Intern. Conf. on Toxic Dinofl. Blooms. Elsevier, Amsterdam, p. 77-82

Mulligan, J. F. (1975). Oceanographic factors associated with New England red tide blooms. In: LoCiero, V. R. (ed.) Proc. First Intern. Conf. Toxic Dinofl. Blooms. Mass. Sci. Tech. Found. Wakefield, Mass., p. 23-40

Murphy, L. S., Guillard, R. R. L., Brown, J. F. (1984). The effects of iron and manganese on copper sensitivity in diatoms: differences in the responses of closely related neritic and oceanic species. Biol. Oceanogr. 3: 187-201

Murray, J. W. (1979). Iron oxides. In: Burns, R. G. (ed.) Marine minerals. Reviews in Mineralogy, Mineralogical Society of America, Vol. 6, p. 47-98

Pingree, R. D., Pugh, P. R., Holligan, P. M., Forster, G. R. (1975). Summer phytoplankton blooms and red tides along tidal fronts in the approaches to the English Channel. Nature, Lond. 258: 672-677

Prakash, A., Rashid, M. A. (1968). Influence of humic substances on growth of marine phytoplankton, dinoflagellates. Limnol. Oceanogr. 13: 598-606

Roberts, B. (1979). Occurrence of Gymnodinium breve red tides long the west and east coasts of Florida during 1976 and 1977. In: Taylor, D. L., Seliger, H. H. (eds.) Toxic dinoflagellate blooms. Proc. Sec. Intern. Conf. on Toxic Dinofl. Blooms. Elsevier, Amsterdam, p. 199-202
Robinson, M. G., Brown, L. N. (1983). A recurrent red tide in a British Columbia coastal lagoon. Can. J. Fish. Aquat. Sci. 40: 2135-2143

Rounsefell, G. A., Dragovich, A. (1966). Correlation between oceanographic factors and abundance of the Florida redtide (Gymnodinium breve Davis), 1954-1961. Bull. mar. Sci. 16: 402

Schenck, R. C. (1984). Copper deficiency and toxicity in Gonyaulax tamarensis (Lebour). Mar. Biol. Lett. 5: 13-19

Slobodkin, L. W. (1953). A possible initial condition for red tides on the coast of Florida. J. mar. Res. 12: 148-155

Smayda, T., Packard, T. (1979). The phenomenon of anoxia as related to dinoflagellate blooms. In: Taylor, D. L., Seliger, H. H. (eds.) Toxic dinoflagellate blooms, Proc. Sec. Intern. Conf. on Toxic Dinofl. Blooms. Elsevier, Amsterdam, p. $456-458$

Steidinger, K. A. (1975). Basic factors influencing red tides. In: LoCicero, V. R. (ed.) Proc. First Intern. Conf. Toxic Dinofl. Blooms. Mass. Sci. Tech. Found., Wakefield, Mass., p. 153-162

Sweeney, B. M. (1975). Red tides I have known. In: LoCicero, V. R. (ed.) Proc. First Intern. Conf. Toxic Dinofl. Blooms. Mass. Sci. Tech. Found., Wakefield, Mass., p. 225-234

Thayer, P. E., Hurst, J. W., Lewis, C. M., Selvin, R., Yentsch, C. M. (1983). Distribution of resting cysts of Gonyaulax tamarensis var. excavata and shellfish toxicity. Can. J. Fish. Aquat. Sci. 40: 1308-1314

Van der Giessen, A. A. (1968). Chemical and physical properties of iron (III)-oxide hydrates. Philips Res. Rep., Suppl. No. $12: 1-88$

Watras, C. J., Chisholm, S. W., Anderson, D. M. (1982). Regulations of growth in an estuarine clone of Gonyaulax tamarensis (Lebour): salinity-dependent temperature responses. J. exp. mar. Biol. Ecol. 62: 25-37

Wells, M. L., Zorkin, N. G., Lewis, A. G. (1983). The role of colloid chemistry in providing a source of iron to phytoplankton. J. mar. Res. 41: 731-746

Wells, M. L., Mayer, L. M. (in press). Variations in the lability of iron in estuarine, coastal and shelf waters and its implications for phytoplankton. Mar. Chem.

Wells, M. L., Mayer, L. M., Guillard, R. R. L. (in press). A chemical method for estimating the availability of iron to phytoplankton in seawater. Mar. Chem.

Wilson, W. B. (1966). The suitability of seawater for the survival and growth of Gymnodinium breve Davis: and some effects of phosphorus and nitrogen on its growth. Prof. Pap. Ser. mar. Lab. Fla. 7: 1-42

Yentsch, C. M., Holligan, P. M., Balch, W. M., Tvirbutas, A. (1986). Tidal stirring vs. stratification: microalgal dynamics with special reference to cyst-forming, toxin producing dinoflagellates. In: Bowman, J., Yentsch, M., Peterson, W. T. (eds.) Tidal mixing and plankton dynamics, Vol. 17, Lecture notes on coastal and estuarine studies. SpringerVerlag, Berlin, Heidelberg, p. 224-252

Yentsch, C. M., Incze, L. S. (1979). Accumulations of algal biotoxins in mussels. In: Lutz, R. (ed.) Mussel culture in North America. Elsevier-North Holland, Amsterdam, p. 223-246

Yentsch, C. M., Mague, F. (1979). Mechanisms and conditions of intoxification and dinoflagellate blooms. In: Taylor, D. L., Seliger, H. H. (eds.) Toxic dinoflagellate blooms. Proc. Sec. Intern. Conf. on Toxic Dinofl. Blooms. Elsevier, Amsterdam, p. $127-130$ 